\title{
Post Harvest studies of Macrocybe gigentium, the Giant Mushroom for Increasing Shelf Life
}

\author{
Megha Suman and Geeta Sharma* \\ Department of Plant Pathology, College of Agriculture, GBPUA\&T, \\ Pantnagar-263 145, Uttrakhand, India \\ *Corresponding author
}

\section{Keywords}

Giant mushroom, Post Harvest, Shelf life,

Freezing

Article Info

Accepted:

17 June 2018 Available Online: 10 July 2018

\section{A B S T R A C T}

Macrocybe gigantium, commonly known as Giant mushroom, belongs to the family Tricholomataceae of the order Agaricales is a genus of fungus which is found worldwide that contains a large number of fairly fleshy, white-spored, gilled mushrooms. This is an edible mushroom having white sporophore, large sized fruit bodies (unique texture, taste) attractive colour and sustainable yield. The temperature requirement for the cultivation of this mushroom is $25-35^{\circ} \mathrm{C}$. The shelf life of all the mushrooms is a great challenge for increasing their acceptability among the consumers. Considering this, the present investigation was carried out on post harvest studies of this mushroom. The sporophores of $M$. giganteum (with and without blanching, WB and WOB, respectively), were steeped in solution of different chemicals like Salt, Sugar, Citric acid (CA), Ascorbic acid (AA) and Potassium Meta-bi-sulphite (KMS) for better shelf life. The results revealed that the fruit bodies preserved in chemical solutions of $\mathrm{T} 1(2 \%$ salt $+2 \%$ sugar $+0.3 \%$ citric acid + $0.1 \% \mathrm{KMS}+1 \%$ ascorbic acid) (without blanching) retained good colour and appearance till 90 days. Thereafter it became slightly dull (scale 2) but it was acceptable up to 180 days of treatment. The texture of sporophores preserved in steeping solutions of treatments of T2 (2\% Salt, 2\% Sugar, 0.3\% CA, 0.1\% KMS and 1\%AA (WOB)), T4 (5\% Salt, 0.2\% CA, 0.1\% KMS (WOB)) and T6 (0.1\% AA, 0.1\% CA, 0.1\% KMS (WOB)) were found almost fresh up to 90 days. The sporophores or the mushroom fruitbodies retained good colour, texture, appearance and acceptability till 9 days under freezing conditions of storage while in deep freezing conditions the colour was retained up to 17 days.

\section{Introduction}

Mushrooms are one such component that impart diversification and also help in addressing the problems of quality food, health and environmental sustainability.
Mushrooms represent microbial technology that recycles agricultural residues into food and manure. Macrocybe gigantium, commonly known as Giant mushroom, belongs to the family Tricholomataceae of the order Agaricales. It is a genus of fungi which is 
found worldwide that contains a large number of fairly fleshy, white-spored, gilled mushrooms. This mushroom requires $25-35^{\circ} \mathrm{C}$ temperature and have large cap with long, thick fibrous stalk (stipe) having white spherical cap (pileus) around $7-8 \mathrm{~cm}$ diameter and average weight of fruit body is $30-50 \mathrm{gm}$. The mushroom does not have off smell. It can be stored up to 2-3 days at room temperature $\left(20-26^{\circ} \mathrm{C}\right)$.

The mushroom species not only having good colour, texture and smell are considered as quality mushroom but the shelf life or keeping quality is also an important criterion to increase the interest of the consumers. Various scientists working in the area are doing experimentations time to time and their findings say that texture was an important quality parameter for fresh mushrooms. One of the main changes associated with mushrooms deterioration were changes in their texture. Mushroom browning was an important cause of loss of quality during postharvest storage (Briones et al., 1992; Briones et al., 1993; Braaksma et al., 1994; Villaescusa and Gil 2003; Ares et al., 2006 and Parentelli et al., 2007). According to Zivanovic et al., (2000) these texture changes were also related to protein and polysaccharide degradation, hyphal shrinkage, central vacuole disruption and expansion of intercellular space at the pileus surface.

The inherent quality of mushroom is one factor that is important for the keeping quality of the mushrooms but the packaging material, temperature for storage and the treatment with various food grade chemicals before packing also plays role. Plaza et al., (1995) reported that the atmosphere in PE packages $\left(10 \% \mathrm{O}_{2}+\right.$ $7 \% \mathrm{CO}_{2}$ ) delayed firmness-loss but induced the metabolic changes (sugar and organic acids) and colour (yellowness) and reduced mushroom quality at $18^{\circ} \mathrm{C}$ after 8 days of storage at $3^{\circ} \mathrm{C}$. Murr and Morris (1975) and
Rai and Saxena (1988) observed that storage of Agaricus bisporus at higher temperature (18 to $20^{\circ} \mathrm{C}$ ) resulted in reduction in protein with accumulation of free amino acids due to activated protease enzyme activity.

Hammond (1979) reported that at higher temperature, urea accumulation and break down of nucleic acids and other nitrogenous substances may occur in Agaricus bisporus. Namdev (2000) reported the preservation of $P$. flabellatus fruit bodies upto 165-175 days in chemical solution of $5 \%$ salt, $0.2 \%$ CA, $0.1 \%$ KMS along with blanching. Storage of whole blanched mushrooms up to 6 months without affecting the colour, flavor and texture was also reported by Rai and Sohi (1988).

Sharma and Thakur (2012) studied the effect of chemical preservatives, freezing and deep freezing on the storage and the shelf life of sporophores of $P$. florida. Kumar et al., (2014) observed that chemical solution of $2 \%$ salt, $2 \%$ sugar, $0.3 \%$ citric acid, $0.1 \% \mathrm{KMS}$ and $1 \%$ ascorbic acid was also found suitable for steeping preservation of mushrooms. It helps to extend shelf life of Agaricus bisporus. All these experiments are related to the other species of mushrooms except the $M$. Gigentium because the work done so far on this mushroom is based on the domestication and production techniques. Keeping above in mind the present investigations are done to study the shelf life and keeping quality of this mushroom.

\section{Materials and Methods}

The crop of giant mushroom was raised as per the standard technology, according to which, the substrate (wheat straw) was prepared by chemical sterilization method, spawning is done @ 4\% of the wet weight of substrate employing thorough method of spawning, thereafter the bags were kept in crop room maintaining $30-35^{\circ} \mathrm{C}$ temperature and $80-85 \%$ 
relative humidity, in the month of may. After 12-15 days of spawning casing was done and fruit bodies were harvested after maturity.

\section{Effect of freezing, deep freezing and room temperature on quality and Shelf life}

The fresh sporophores of $M$. giganteum weighing about $30 \mathrm{gm}$ per fruitbody were taken and cleaned with water. These were then kept in polythene bags and preserved at room temperature $\left(35 \pm 2^{\circ} \mathrm{C}\right)$, in refrigerator $\left(4^{\circ} \mathrm{C}\right)$ and in deep freezer at $\left(-10^{\circ} \mathrm{C}\right)$.

The stored samples were monitored regularly for any change in colour, texture and overall acceptability.

Three replications were maintained for each treatment. The observations on quality parameters were recorded using 1-5 scale for colour, 1-7 scale for texture and 1-6 scale for appearance as described by Sharma and Thakur (2012).

\section{Effect of chemical preservatives on shelf life and quality}

To study the quality and shelf life, the sporophores of $M$. giganteum (with and without blanching), were steeped in solution of different chemicals. The fresh sporophores (30-35gm) were blanched at $98^{\circ} \mathrm{C}$ for $2-3 \mathrm{~min}$, using double layer of muslin cloth.

Thereafter, the sporophores were transferred in the steeping solutions prepared from various concentrations of different chemicals forming 8 treatments.

The steeping solution of $500 \mathrm{ml}$ was taken in a plastic container of 1 liter capacity and lid was screwed. These containers were then stored at room temperature and observations on color, texture, appearance and overall acceptability (in days) were recorded on the basis of various given scales at different time intervals.

\section{Results and Discussion}

Effect of freezing and deep freezing on quality and shelf life

It was observed during the study that the sporophores of strains MA-2 and MA-3 retained good colour till 9 days under freezing conditions of storage while in deep freezing condition the colour was retained only by strain MA-3 up to 13 days (Table 1). Sporophores of MA-1 and MA-4 retained good colour till 5 days under freezing conditions of storage while in deep freezing conditions the colour was retained up to 9 days whereas, sporophores of MA-2 retained good colour till 5 days in both freezing and deep freezing condition.

The data showed the texture of sporophores of all the strain was good till 5 days in freezing condition while in deep freezing condition only MA-2 and MA-4 was retained up to13 days, whereas strains MA-1 and MA-3 was retained up to 9 days.

The appearance of sporophore of strains was fair up to 9 days in strains MA-1, MA-2 and MA-3 while, in strains MA-4 it was fair up to only 5 days in freezing condition. Whereas, in deep freezing conditions sporophores were fair up to 13 days in all the strains of test fungus. While the sporophores kept at room temperature $\left(35 \pm 2^{\circ} \mathrm{C}\right)$ look fresh for first two days then their pileus start shrinking day by day up to 9 days, due to high evaporation rate in summers.

The studies done by various scientists on the preservation of the mushrooms showed that sporophores of Pleurotus ostreatus, $P$. flabellatus, Agaricus bisporus and Volvariella volvacia could be well stored for 3 months at $30^{\circ} \mathrm{C}$ with pre freezing treatments (Namdev, 2000, Saxena and Rai, 1988, Sethi and Anand,1984) and confirms the findings of present experiment. 
Table.1 Effect of freezing and deep freezing on quality and shelf life

\begin{tabular}{|c|c|c|c|c|c|c|c|c|c|c|c|c|c|c|c|c|c|c|c|c|c|c|}
\hline Specification & Strains & \multicolumn{7}{|c|}{$\begin{array}{c}{ }^{1 .} \text { Colour of sporophores at } \\
\text { different time intervals (days) }\end{array}$} & \multicolumn{7}{|c|}{$\begin{array}{l}\text { 2.Texture of sporophore at time } \\
\text { intervals (days) }\end{array}$} & \multicolumn{7}{|c|}{$\begin{array}{c}{ }^{3} \text { Sporophore appearance at time } \\
\text { intervals (days) }\end{array}$} \\
\hline \multirow{5}{*}{$\begin{array}{l}\text { Freezing } \\
\left(4^{\circ} \mathrm{C}\right)\end{array}$} & & 1 & 3 & 5 & 9 & 13 & 17 & 21 & 1 & 3 & 5 & 9 & 13 & 17 & 21 & 1 & 3 & 5 & 9 & 13 & 17 & 21 \\
\hline & MA-1 & 1 & 2 & 3 & 4 & 5 & 5 & - & 1 & 1 & 2 & 3 & 4 & 6 & & 1 & 1 & 3 & 4 & 5 & 6 & - \\
\hline & MA-2 & 1 & 1 & 2 & 3 & 4 & 5 & - & 1 & 1 & 2 & 4 & 5 & 7 & & 1 & 1 & 4 & 4 & 5 & 6 & - \\
\hline & MA-3 & 1 & 1 & 2 & 3 & 4 & 5 & - & 1 & 1 & 2 & 3 & 5 & 7 & & 1 & 1 & 3 & 4 & 5 & 6 & - \\
\hline & MA-4 & 1 & 2 & 3 & 4 & 5 & 5 & - & 1 & 1 & 2 & 4 & 5 & 7 & & 1 & 1 & 4 & 5 & 6 & 6 & - \\
\hline & & & & & & & & & & & & & & & & & & & & & & \\
\hline \multirow{4}{*}{$\begin{array}{l}\text { Deep Freezing } \\
\left(-10^{\circ} \mathrm{C}\right)\end{array}$} & MA-1 & 1 & 1 & 2 & 3 & 4 & 4 & 5 & 1 & 1 & 1 & 2 & 4 & 4 & 7 & 1 & 1 & 2 & 4 & 4 & 6 & 6 \\
\hline & MA-2 & 1 & 1 & 3 & 4 & 4 & 5 & 5 & 1 & 1 & 1 & 2 & 2 & 5 & 7 & 1 & 1 & 2 & 3 & 4 & 5 & 6 \\
\hline & MA-3 & 1 & 1 & 2 & 2 & 3 & 3 & 5 & 1 & 1 & 1 & 2 & 4 & 4 & 7 & 1 & 1 & 2 & 3 & 4 & 5 & 6 \\
\hline & MA-4 & 1 & 1 & 1 & 3 & 4 & 5 & 5 & 1 & 1 & 1 & 2 & 2 & 5 & 7 & 1 & 1 & 2 & 3 & 4 & 5 & 6 \\
\hline
\end{tabular}

'Scale: White-1; Like white- 2; Slight dull-3; Light yellow-4; Dark yellow-5

${ }^{2}$ Scale: Fresh-1; Like fresh-2; Less soggy-3; More soggy-4; Coarse-5; Rotting-6; Leathery-7

${ }^{3}$ Scale: Fresh-1; Very good-2; Good-3; Fair-4; Slight fermented smell-5; Unacceptable-6 
Table.2 Effect of chemical preservatives on quality and shelf life

\begin{tabular}{|c|c|c|c|c|c|c|c|c|c|c|c|c|c|c|c|c|c|c|c|c|c|c|c|c|c|c|c|c|c|c|}
\hline \multirow{3}{*}{$\begin{array}{l}\text { T.No. } 1 \\
\begin{array}{l}\text { Treatme } \\
\text { nt }\end{array}\end{array}$} & \multirow[b]{2}{*}{1} & \multicolumn{9}{|c|}{$\begin{array}{c}\text { 1. Colour of sporophores at different time } \\
\text { intervals (days) }\end{array}$} & \multicolumn{10}{|c|}{$\begin{array}{c}{ }^{2 \cdot} \text { Texture of sporophore at time intervals } \\
\text { (days) }\end{array}$} & \multicolumn{10}{|c|}{$\begin{array}{c}{ }^{3 .} \text { Sporophore appearance at time intervals } \\
\text { (days) }\end{array}$} \\
\hline & & 5 & 1 & 2 & 3 & 6 & 9 & 12 & 15 & 18 & 1 & 5 & 1 & 2 & 3 & 6 & 9 & 12 & 15 & 18 & 1 & 5 & 1 & 2 & 3 & 6 & 9 & 12 & 15 & 18 \\
\hline & & & 0 & 0 & 0 & 0 & 0 & 0 & 0 & 0 & & & 0 & 0 & 0 & 0 & 0 & $\mathbf{0}$ & $\mathbf{0}$ & 0 & & & 0 & 0 & 0 & $\mathbf{0}$ & 0 & 0 & 0 & 0 \\
\hline $\mathbf{T 1}$ & 1 & 1 & 3 & 4 & 5 & 6 & & & & & 1 & 2 & 3 & 3 & 4 & 6 & & & & & 1 & 2 & 3 & 4 & 5 & 6 & & & & \\
\hline $\mathbf{T} 2$ & 1 & 1 & 1 & 1 & 1 & 1 & 1 & 2 & 3 & 4 & 1 & 1 & 2 & 2 & 2 & 2 & 2 & 3 & 5 & 5 & 1 & 2 & 2 & 2 & 3 & 3 & 3 & 3 & 4 & 4 \\
\hline T3 & 1 & 1 & 1 & 1 & 1 & 1 & 1 & 2 & 4 & & 1 & 1 & 2 & 2 & 2 & 3 & 4 & 5 & 6 & & 1 & 2 & 2 & 2 & 2 & 3 & 4 & 4 & 5 & 6 \\
\hline T4 & 1 & 1 & 1 & 1 & 2 & 3 & 5 & 6 & & & 1 & 1 & 2 & 2 & 2 & 2 & 2 & 4 & 5 & & 1 & 2 & 2 & 2 & 2 & 3 & 3 & 4 & 4 & 5 \\
\hline T5 & 1 & 1 & 1 & 3 & 3 & 5 & 6 & & & & 1 & 1 & 2 & 3 & 4 & 5 & 6 & & & & 1 & 2 & 2 & 3 & 3 & 4 & 5 & & & \\
\hline T6 & 1 & 1 & 1 & 1 & 2 & 3 & 4 & 5 & 6 & & 1 & 1 & 2 & 2 & 2 & 2 & 2 & 4 & 5 & 6 & 1 & 2 & 2 & 2 & 2 & 3 & 4 & 5 & 5 & \\
\hline T7 & 1 & 5 & & & & & & & & & 1 & 6 & & & & & & & & & 1 & 6 & & & & & & & & \\
\hline T8 & 1 & 6 & & & & & & & & & 1 & 6 & & & & & & & & & 1 & 6 & & & & & & & & \\
\hline
\end{tabular}

${ }^{1}$ Scale: White-1; Slight dull-2; Light yellow-3; Dark yellow-4; Light brown-5; Dark brown-6

${ }^{2}$ Scale: Fresh-1; Like fresh-2; Less soggy-3; More soggy-4; Coarse-5; Rotting-6; Leathery-7

${ }^{3}$ Scale: Fresh-1; Very good-2; Good-3; Fair-4; Slight fermented smell-5; Unacceptable-6

\begin{tabular}{|l|c|c|c|c|c|c|c|}
\hline \multicolumn{7}{|c|}{ Scale used for colour, texture and appearance } \\
\hline & $\mathbf{1}$ & $\mathbf{2}$ & $\mathbf{3}$ & $\mathbf{4}$ & $\mathbf{5}$ & $\mathbf{6}$ & $\mathbf{7}$ \\
\hline Scale for colour & White & Like white & Slight dull & Light brown & Dark yellow & Light brown & Dark brown \\
\hline Scale for texture & Fresh & Like fresh & Less soggy & More soggy & Coarse & Rotting & Leathery \\
\hline $\begin{array}{l}\text { Scale for } \\
\text { appearance }\end{array}$ & Fresh & Very good & Good & Fair & $\begin{array}{c}\text { Slight fermented } \\
\text { smell }\end{array}$ & Unacceptable & - \\
\hline
\end{tabular}




\begin{tabular}{|l|l|}
\hline \multicolumn{2}{|c|}{ Treatment number and details } \\
\hline $\mathrm{T}_{1}$ & $2 \%$ Salt, $2 \%$ Sugar, 0.3\% CA, 0.1\% KMS and 1\%AA (WB) \\
\hline $\mathrm{T}_{2}$ & $2 \%$ Salt, $2 \%$ Sugar, $0.3 \% \mathrm{CA}, 0.1 \% \mathrm{KMS}$ and $1 \% \mathrm{AA}(\mathrm{WOB})$ \\
\hline $\mathrm{T}_{3}$ & $5 \%$ Salt, $0.2 \% \mathrm{CA}, 0.1 \% \mathrm{KMS}(\mathrm{WB})$ \\
\hline $\mathrm{T}_{4}$ & $0.1 \%$ AA, $0.1 \% \mathrm{CA}, 0.1 \% \mathrm{KMS}(\mathrm{WB})$ \\
\hline $\mathrm{T}_{5}$ & $0.1 \%$ AA, $0.1 \% \mathrm{CA}, 0.1 \% \mathrm{KMS}(\mathrm{WOB})$ \\
\hline $\mathrm{T}_{6}$ & Boiled Tap water \\
\hline $\mathrm{T}_{7}$ & Normal Tap water \\
\hline $\mathrm{T}_{8}$ & \\
\hline
\end{tabular}

CA- Citric acid; AA- Ascorbic acid; KMS- Potassium metabisulphite; WB- With blanching, WOB- Without blanching. 
It will be beneficial for the persons working commercially with the mushrooms because the fruitbodies could be stored for longer period without deteriorating the quality.

\section{Effect of chemical preservatives on quality and shelf life}

Studies conducted on preservation of mushrooms and the effect of chemical preservatives on colour, texture and appearance of giant mushroom were done with the sporophores of strain MA-3 and the observations recorded are depicted in table 2 . The data show that the treatment $\mathrm{T} 2$ and $\mathrm{T} 3$ retained white colour (1) of the sporophore of giant mushroom till 90 days. Thereafter it became slightly dull (2) but it was acceptable up to 120 days. It was followed by treatment T4 and T6 which could equally preserve the sporophores by retaining the white (1) colour till 20 days and acceptable up to 30 days. Whereas, T5 retained white colour only for 10 days and in remaining treatments i.e. in $\mathrm{T} 1$, T7 and T8, acceptable colour of sporophores could be maintained even up to 10 days. The sporophores kept under these treatments exhibited quick deterioration. In case of treatments $\mathrm{T} 1, \mathrm{~T} 5, \mathrm{~T} 7$ and $\mathrm{T} 8$ chemical preservatives became turgid, less transparent and profuse growth of fungal contaminants occurred on the top of the solution, which gave foul smell.

The texture of sporophores preserved in steeping solutions of treatment T2, T4 and T6 were almost fresh (2) up to 90 days. In treatments T3 and T5 the sporophores were like fresh (2) till 10 days. Treatment T2, T4 and T6 showed coarse texture within 150 days. The sporophores preserved in $\mathrm{T} 7$ and T8 treatments showed rotting within 5 days which was unacceptable for consumption. Sporophores preserved in steeping solutions of treatments T2 was well (2) up to 120 days whereas, T2, T3, T4 and T6 were fair up to 60 days of storage period. While the mushrooms kept in treatments $\mathrm{T} 7$ and $\mathrm{T} 8$ became unacceptable even within 5 days of storage.

So, according to the experiment conducted and results showed, treatment $\mathrm{T} 2$ is the best chemical preservative for the long duration preservation of giant mushroom and another finding is without blanching is more appropriate than the blanching method.

These results are in accordance with the findings of experiment done by Sharma and Thakur (2012) with $P$. florida on the effect of chemical preservatives, freezing and deep freezing on the storage and the shelf life.

As the shelf life of most of the mushroom is very short and which is the main drawback for long distance transportation of the mushroom. Any type of dis-colouration, loss of turgidity and off smell due to bruising is the main factor for unacceptability of the mushrooms among consumers. so, there is need to either enhance the shelf life of the mushrooms genetically or develop any techniques through which the mushrooms could be preserved for longer duration. Therefore, the findings of the experiment may be helpful to fulfil the need of mushroom growers as well as consumers during the course of present investigation.

\section{References}

Ares G, Parentelli C, Gámbaro A, Lareo C and Lema P 2006. Sensory shelf life of shiitake mushrooms stored under passive modified atmosphere. Postharvest Biology and Technology. 41: 191-197.

Briones LG, Varoquaux $\mathrm{P}$, Bureau $\mathrm{G}$ and Pascat B 1993. Modified atmosphere packaging of common mushroom. Int. J. Food Sci. and Tech. 28: 57-68. 
Briones LG, Varoquaux P, Yves C, Bouquant J, Bureau G and Pascat B 1992. Storage of common mushroom under controlled atmospheres. Int. J. Food Sci. and Tech. 27: 493-505.

Braaksma A, Schaap DJ, Jongen WMF and Woltering EJ 1994. Ageing of mushroom (Agaricus bisporus) under post-harvest conditions. Postharvest Biology and Technology. 4: 99-110.

Hammond JBW 1979. Changes in composition of harvested mushrooms Agaricus bisporus. Phytochem. 18(3): 415-418.

Kumar S, Chand G, Srivastava JN and Ahmad S Md. 2014. Postharvest Technology of Button Mushroom: A Socio-Economic Feasibility. J. Post harvest Tech. 202: 136-145.

Murr DP and LL Morris 1975. Effect of storage temperature on postharvest changes in mushroom. J. Amer. Soc. Hort. Sci. 100(1): 16-19.

Namdev JK 2000. Studies on production and preservation technique of Oyster mushroom ( $P$. flabellatus). Thesis, M.Sc. IGAU, Raipur. 82p.

Plaza JL, Alique R, Zamorano JP, Calvo ML and Navarro MJ 1995. Effect of the high permeability to $\mathrm{O}_{2}$ on the quality changes and shelf-life of fresh mushrooms stored under modified atmosphere packaging. Mushroom Science. 14(2):709-716.

Parentelli C, Ares G, Corona M, Lareo C, Gámbaro $\mathrm{A}$, Soubes $\mathrm{M}$ and Lema $\mathrm{P}$ 2007. Sensory and microbiological quality of shiitake mushrooms in modified atmosphere packages. J. Sci. Food and Agri. 1: 86-97.

Rai RD and Saxena S 1988. Effect of storage temperature on vitamin $\mathrm{C}$ content of mushroom (Agaricus bisporus). Curr. Sci. 57: 434-435.

Rai RD and Sohi HS 1988. How protein rich are mushrooms. Indian hortic. 33(2):23.

Sharma LR and Thakur PM 2012. Studies on post harvest management of Oyster mushroom (Pleurotus florida). Mush. Res. 21(2): 151-155.

Sethi V and Anand JC 1984. Nutritional quality of edible mushrooms. Indian Mushroom Science-II. Proceedings of the international conference on silver jubilee symposium on science and cultivation technology of edible fungi held on 9-11th September, 1983 at Srinagar. RRL, Jammu and Kashmir (CSIR).

Saxena S and Rai RP 1988. Storage of button mushroom (A. bisporus L.). The effect of temperature, perforation of packs and pre treatment with KMS. Mush. J. Tropics. 8:15-22.

Villaescusa R and Gil MI 2003. Quality improvement of Pleurotus mushrooms by modified atmosphere packaging and moisture absorbers. Post harvest Biol. Tech. 28: 169-179.

Zivanovic S, Buescher RW and Kim KS 2000. Textural changes in mushrooms Agaricus bisporus associated with tissue ultra structure and composition. J. Food Sci. 65: 1404-1408.

\section{How to cite this article:}

Megha Suman and Geeta Sharma. 2018. Post Harvest studies of Macrocybe gigentium, the Giant Mushroom for Increasing Shelf life Int.J.Curr.Microbiol.App.Sci. 7(07): 2365-2372. doi: https://doi.org/10.20546/ijcmas.2018.707.275 